\title{
Aptamers Based Biosensors for Disease Detection
}

\author{
Suveen Kumar* \\ Department of Biotechnology, Delhi Technological University, India
}

Submission: April 03, 2017; Published: April 28, 2017

"Corresponding author: Suveen Kumar, Department of Biotechnology, Delhi Technological University, Delhi Technological University, Delhi-110042, India, Email: suveendev@gmail.com

\begin{abstract}
From last two decades, it has been observed that the Aptamer has immense potential to work as a recognition element in the fabrication of efficient biosensing platform. On comparing with the traditional biorecognition elements such as antibody, enzyme etc. It has been observed that Aptamers have numerous advantages on these traditional biorecognition elements in terms of size, chemical stability, sensitivity, selectivity and cost. Recently it has been observed that, in the integration with nanomaterials, Aptamer based biosensor shows improved biosensing characteristics of fabricated electrodes. Keeping these in view, this review contains the summery of advancement in the development of aptamer based biosensors for disease detection in last five years.
\end{abstract}

\section{Introduction}

In the fabrication of biosensor, biorecognition elements or bioreceptorplay an important role. Bioreceptor is a biological molecular species (e.g. antibody, enzyme or nucleic acid) or a living biological system (e.g. cells, tissues or whole organisms) that has capability to recognize a target or substrate (analyte) molecules [1]. Bio-recognition elements have unique profile that helps in providing strong affinity for a specific molecule. This specific feature provides biosensor to become highly selective in nature. Different types of bioreceptors such as enzyme, nucleic acid, cell, antibodies, aptamers etc. are being widely used for the fabrication of a biosensor [2-7]. In these bioreceptors, Aptamers shows imminence potential in the fabrication of biosensor. Aptamers are double stranded DNA or single stranded RNA or DNA strands that bind specifically to molecular targets [8]. These "designer" molecules were first developed in 1990 and were followed by the development of systemic evolution of ligands by exponential enrichment (SELEX), which is the technology for isolation of highly specific aptamers. However, a study in 2000's revealed the presence of "riboswitches"-a type of naturallyoccurring RNA aptamers that function as gene regulators in the cell nucleus. Owing to their small size, high affinity for targets and high pH and temperature stability, aptamers have been under intense investigation for a number of applications, including targeted therapeutics and diagnostics [9].

One of the potential applications for aptamers is as detection probes in immunosensors. The small size of aptamers, presence of predictable secondary structures and the easy tunability in their structures (owing to conformational changes) allow for different biosensing strategies that were not earlier with only enzymes or antibodies as biorecognition molecules [1012]. As biorecognition element, aptamers possess a number of advantages over antibodies and enzymes, such as high selectivity even for those targets which are not easily recognized by antibodies (e.g., ions, small molecules, etc.), ease of chemical modification, flexibility in structure and conformation, high $\mathrm{pH}$ stability and reversible thermal denaturation, cheaper production costs, and so on and so forth. Moreover, aptamerbased ELISA and other immunosensing strategies have been found to be more reproducible, robust and economical than the conventional assays. In a novel approach, Jolly et al. [12] developed an aptamer-based ELISA for quantitative analysis of free prostate specific antigen (fPSA) in a microfluidic system. In this study, DNA aptamers specific to fPSA were immobilized onto PDMS microfluidic channels using silane chemistry and quantification was performed by HRP-labeled anti-PSA antibodies yielding a sandwich ELISA format. This biosensor was shown to follow a Hill dose-response relation with a dissociation constant of 9.8ng mL-1 and could detect fPSA in a wide linear range of 0.01-50ng mL-1 [13]. An HRP-labeled lectin probe was also utilized to analyze the glycoprofiles of the PSA molecules. This study is significant in that it showed the importance of using aptamers in place of antibodies as capture probes by comparing the specificity of this biosensor to that of a conventional ELISA. Herein, the reported aptamer based immunoassay was shown to efficiently differentiate PSA from human Kallekrein 2 (hK2), 
a protein that has $80 \%$ homology to PSA. On the other hand, conventional ELISA was found to be highly cross-reactive and unable to differentiate between PSA and hK2. This study proved that aptamers are more specific and selective than antibodies as biorecognition probes. Ilkhani et al. [13] reported an electrochemical aptamer/antibody based sandwich assay for the detection of EGFR, a cancer biomarker. This work utilized EGFR-specific aptamers immobilized onto streptavidin-coated magnetic beads (MBs) as capture probes and gold nanoparticles (AuNP)-labeled anti-EGFR antibodies as the detector/signal probe. This biosensor was shown to display a wide range of detection (1-40ng mL-1) with good detection limit (50pgmL1). The performance of the biosensor was also analyzed against serum samples from breast cancer patients. Kavosi et al. [14] utilized aptamers as detection probes and developed a triple signal amplification strategy for ultrasensitive detection of PSA in real samples. In this approach, anti-PSA antibodies were covalently attached to graphene oxide/chitosan-modified glassy carbon electrodes and thionine was used as redox label. A sandwich assay was achieved by the addition of HRP-labeled PSA-aptamers that were covalently linked to polyamidoamine (PAMA)-encapsulated gold nanoparticles (Au-PAMA). The use of labeled aptamers enhanced the specificity and reduced interference by other moieties present in the matrix and hence, the biosensor displayed an excellent detection limit of $10 \mathrm{fg}$ mL-1 in a wide linear range. Taleat et al. [15] reported on the development of an electrochemical biosensor based on poly o-aminobenzoic acid (PABA)-modified graphite electrodes and utilized the antibody-target-aptamer sandwich strategy for the detection of MUC1 cancer biomarker. This study utilized methylene blue (MB) as redox indicator that directly interacts with the G residues present in the MUC1-specific aptamers, thus bypassing the need of additional chemical labeling steps and simplifying the fabrication process. This aptamer-mediated immunosensor was shown to detect MUC1 in the range of 1-12 ppb with a detection limit of $0.62 \mathrm{ppb}$ [16].

As mentioned above, aptamers can be used to detect small molecules which do not have enough epitopic determinants to be specifically detected by antibodies. While antibodies can be cross-reactive where two molecules are same but at a single functional position, aptamers have shown to be highly selective for only one of them [17]. This property of aptamers was exploited by Xiang et al. [18] when they developed a sandwich antibody-target-aptamer assay for the detection of microcystinleucine-arginine (MC-LR), which is a hepatotoxin and a potential bioweapon. Thus in this study, the authors sought to utilize MC-LR specific aptamers immobilized onto the glass surface of a portable analyzer as biorecognition molecules. Anti-MC-LR antibodies labeled with HRP were used as detector probes. The biosensor showed fairly good sensitivity $(0.3 \mu \mathrm{g} \mathrm{mL}-1)$, but the main highlight of this device was its excellent specificity towards MC-LR when tested against other MCs (e.g., MC-LA, MC-YR, nodularin-R), which are structurally nearly similar to MC-LR and are cross-reactive against anti-MC-LR monoclonal antibodies. The comparative analysis of biosensing parameters of fabricated aptamer based biosensor have been summarized in Table 1.

Table 1: Comparative analysis of development of aptamer based biosensors for disease detection.

\begin{tabular}{|c|c|c|c|c|c|c|c|}
\hline \multirow{2}{*}{ S. No. } & \multirow{2}{*}{ Biomarker } & \multirow{2}{*}{ Disease } & \multirow{2}{*}{ Techniques } & Nanomaterials/ & \multirow{2}{*}{$\begin{array}{c}\text { Linear } \\
\text { Detection } \\
\text { Range }\end{array}$} & \multirow{2}{*}{$\begin{array}{l}\text { Detection } \\
\text { Limit }\end{array}$} & \multirow{2}{*}{ Ref. } \\
\hline & & & & Substrate used & & & \\
\hline 1. & $\begin{array}{l}\text { Epidermal growth } \\
\text { factor receptor } \\
\text { (EGFR) }\end{array}$ & Cancer & $\begin{array}{l}\text { Differential pulse } \\
\text { voltammetry }\end{array}$ & $\begin{array}{l}\text { Magnetic beads } \\
\text { (MB) }\end{array}$ & $1-40 \mathrm{ng} / \mathrm{mL}$ & $50 \mathrm{pg} / \mathrm{mL}$ & {$[14]$} \\
\hline 2. & $\begin{array}{l}\text { Free prostate } \\
\text { specific antigen } \\
\text { (fPSA) }\end{array}$ & Prostate Cancer & Chemiluminescence & PDMS substrate & $\begin{array}{l}0.01-50 \mathrm{ng} \\
\mathrm{mL}-1\end{array}$ & $0.5 \mathrm{ng} / \mathrm{mL}$ & [13] \\
\hline 3. & $\begin{array}{l}\text { Prostate specific } \\
\text { antigen (PSA) }\end{array}$ & Prostate Cancer & $\begin{array}{l}\text { Differential pulse } \\
\text { voltammetry }\end{array}$ & $\begin{array}{l}\text { Graphene oxide/ } \\
\text { chitosan }\end{array}$ & $\begin{array}{c}0.1 \mathrm{pg} / \mathrm{mL} \text { to } 90 \\
\mathrm{ng} / \mathrm{mL}\end{array}$ & $10 \mathrm{fg} / \mathrm{mL}$ & {$[15]$} \\
\hline 4. & MUC1 & Cancer & $\begin{array}{l}\text { Differential pulse } \\
\text { voltammetry }\end{array}$ & $\begin{array}{l}\text { 0-aminobenzoic } \\
\text { acid polymer/ } \\
\text { graphite }\end{array}$ & $1-12 \mathrm{ppb}$ & $0.62 \mathrm{ppb}$ & {$[16]$} \\
\hline 5. & $\begin{array}{l}\text { microcystin- } \\
\text { leucine-arginine } \\
(M C-L R)\end{array}$ & Liver Cancer & Chemiluminescence & Glass substrate & $0.5-4 \mu \mathrm{g} / \mathrm{L}$ & $0.3 \mu \mathrm{g} / \mathrm{L}$ & [18] \\
\hline 6. & $\begin{array}{l}\text { Carcinoembryonic } \\
\text { antigen (CEA) }\end{array}$ & Cancer & $\begin{array}{l}\text { Differential pulse } \\
\text { voltammetry }\end{array}$ & Au nanosphere & $\begin{array}{c}1 \mathrm{pg} / \mathrm{mL} \text { to } 100 \\
\mathrm{ng} / \mathrm{mL}\end{array}$ & $0.45 \mathrm{pg} / \mathrm{mL}$ & [19] \\
\hline
\end{tabular}

\section{Conclusion and Future Prospects}

From the above reported studies it has been observed that the aptamers play a significant role in the specificity of the biosensor. It have also been pointed that the advantages of using aptamer/antibody sandwich assays in place of traditional ELISA and antibody/antibody sensors. It is worth noting here that automation of SELEX procedures and use of in silico techniques would significantly reduce the processing time of aptamer 
selection and development, which may, in the future, play an important role in widespread use of aptamers in commercial assays and applications in communicable as well as noncommunicable disease detection.

\section{References}

1. Turner A, Karube I, Wilson GS (1987) Biosensors: fundamentals and applications: Oxford University Press, USA.

2. Kumar S, Kumar S, Pandey CM, Malhotra BD (2016) Conducting paper based sensor for cancer biomarker detection. J Phys Conf Ser 1: 1201012018.

3. Kumar S, Sharma JG, Maji S, Malhotra BD (2016) A biocompatible serine functionalized nanostructured zirconia based biosensing platform for non-invasive oral cancer detection. RSC Adv 6: 77037-77046.

4. Kumar S, Sharma JG, Maji S, Malhotra BD (2016) Nanostructured zirconia decorated reduced graphene oxide based efficient biosensing platform for non-invasive oral cancer detection. Biosens Bioelectron 78: 497-504.

5. Patel MK, Ali MA, Krishnan S, Agrawal VV, Kheraif AAA, et al. (2015) A label-free photoluminescence genosensor using nanostructured magnesium oxide for cholera detection. Sci Rep 5: 17384.

6. Kaushik A, Khan R, Solanki PR, Pandey P, Alam J, et al. (2008) Iron oxide nanoparticles-chitosan composite based glucose biosensor. Biosens Bioelectron 24(4): 676-683.

7. Yadav B, Kumar S, Doval DC, Malhotra BD (2017) Development of biosensor for non-invasive oral cancer detection. Eur J Cancer 72: S138-S9.

8. Song S, Wang L, Li J, Fan C, Zhao J (2008) Aptamer-based biosensors. TrAC: Trends Anal Chem 27(2): 108-117.

9. Xiao Z, Farokhzad OC (2012) Aptamer-functionalized nanoparticles for medical applications: challenges and opportunities. ACS nano 6(5): 3670.

10. MacKay S, Wishart D, Xing JZ, Chen J (2014) Developing trends in aptamer-based biosensor devices and their applications. IEEE Trans Biomed Circuits Syst 8: 4-14.
11.Zhu Z, Song Y, Li C, Zou Y, Zhu L, et al. (2014) Monoclonal surface display SELEX for simple, rapid, efficient, and cost-effective aptamer enrichment and identification. Anal Chem 86: 5881-5888.

12.Du F, Alam MN, Pawliszyn J (2014) Aptamer-functionalized solid phase microextraction-liquid chromatography/tandem mass spectrometry for selective enrichment and determination of thrombin. Anal Chim Acta 845: 45-52.

13.Jolly P, Damborsky P, Madaboosi N, Soares RR, Chu V, et al. (2016) DNA aptamer-based sandwich microfluidic assays for dual quantification and multi-glycan profiling of cancer biomarkers. Biosens Bioelectron 79: 313-319.

14.Ilkhani H, Sarparast M, Noori A, Bathaie SZ, Mousavi MF (2015) Electrochemical aptamer/antibody based sandwich immunosensor for the detection of EGFR, a cancer biomarker, using gold nanoparticles as a signaling probe. Biosens Bioelectron 74: 491-497.

15.Kavosi B, Salimi A, Hallaj R, Moradi F (2015) Ultrasensitive electrochemical immunosensor for PSA biomarker detection in prostate cancer cells using gold nanoparticles/PAMAM dendrimer loaded with enzyme linked aptamer as integrated triple signal amplification strategy. Biosens Bioelectron 74: 915-23.

16.Taleat Z, Cristea C, Marrazza G, Mazloum-Ardakani M, Săndulescu R (2014) Electrochemical immunoassay based on aptamer-protein interaction and functionalized polymer for cancer biomarker detection. J Electroanal Chem 717: 119-124.

17.Malhotra S, Pandey A, Rajput Y, Sharma R (2014) Selection of aptamers for aflatoxin M1 and their characterization. J Mol Recogn 27(8): 493500 .

18.Xiang A, Lei X, Ren F, Zang L, Wang Q, et al. (2014) An aptamer-based immunoassay in microchannels of a portable analyzer for detection of microcystin-leucine-arginine. Talanta 130: 363-369.

19.Cheng H, Xu L, Zhang H, Yu A, Lai G (2016) Enzymatically catalytic signal tracing by a glucose oxidase and ferrocene dually functionalized nanoporous gold nanoprobe for ultrasensitive electrochemical measurement of a tumor biomarker. Analyst 141(14): 4381-4387.

\section{Your next submission with Juniper Publishers will reach you the below assets}

- Quality Editorial service

- Swift Peer Review

- Reprints availability

- E-prints Service

- Manuscript Podcast for convenient understanding

- Global attainment for your research

- Manuscript accessibility in different formats

( Pdf, E-pub, Full Text, Audio)

- Unceasing customer service

Track the below URL for one-step submission https://juniperpublishers.com/online-submission.php 